\title{
Macroscopic Aspects of the Cranial Mesenteric Artery (Arteria Mesenterica Cranialis) in Chinchilla Lanigera Species
}

\author{
Cristian MARTONOS, Cristian DEZDROBITU, Florin STAN*, Alexandru GUDEA, Aurel DAMIAN \\ University of Agricultural Sciences and Veterinarian Medicine, Cluj-Napoca, Romania. \\ * corresponding author: florin.stan@usamvcluj.ro \\ Bulletin UASVM Veterinary Medicine 74(2)/2017 \\ Print ISSN 1843-5270; Electronic ISSN 1843-5378 \\ doi:10.15835/buasvmcn-vm:0024
}

\begin{abstract}
In this study we have used 10 carcasses of chinchilla females slaughtered by the owner for commercial purposes. The studied animals have been subjected to an antemortem exam in which the semiological constants like: temperature; breats per minute and pulse were recorded. After the examination the subjects were declared clinically healthy. After skinning $30 \mathrm{ml}$ coloring agent was injected intraluminally and dissection of the cranial mesenteric artery was performed. The first collateral branch of this vessel was the caudal pancreatico-duodenal artery (Arteria pancreaticoduodenalis caudalis), followed by 4-5 jejunal arteries (Arteriae jejunales). The cranial mesenteric artery gives off the dorsal cecal artery (Arteria cecalis dorsalis) as one of terminal branches to supply the haustrated part of cecum, the medial cecal artery (Arteria cecalis media) distributed to the tubular part of cecum (second terminal) and ileocolic artery (Arteria ileocolica)(the third terminal). To the best of our knowledge, our results brings significant information about the blood supply of intestines in chinchilla, that could be a real help for clinicians and researchers studying this topic.
\end{abstract}

Keywords: Chinchilla, cranial mesenteric artery, vascular anatomy

\section{INTRODUCTION}

Chinchillas are small rodents, with nocturnal intense activity. They live freely on the hills of the Andes, between $20^{\circ}-30^{\circ}$ south latitude, up to 3000 meters in the Chilean, Peru, Argentina and southern regions of Bolivia (Martonos et al., 2014; Bud and Ștefan, 2006; Bura, 2003).

Taxonomy includes them in Mammalia class, THERIA subclass, Eutheria group, Rodencia order, Hystricomorpha suborder, Chinchilidae family and Chinchilla species. Speciality literature describes three chinchillas species: Chinchilla lanigera, known as chinchilla from Chile, Chinchilla brevicaudata, or short-tailed chinchilla, which is an endangered species and Chinchilla Rex, an extinct species of chinchilla (Botha, 2009).

In Romania, chinchilla was imported initial as an animal bred for fur, and thanks to its elegant look and its fine fur, this species has become highly appreciated. Besides the economic aspect of chinchilla breeding, we also must discuss the social importance of these small rodents, that became very popular lately as pets (Bura, 2003). Because of these facts, we consider the anatomical description of cardio-vascular system a real benefit for clinicians, researchers and auxiliary medical staff who comes into contact with this animals.

Cranial mesenteric artery (Arteria mezenterica cranialis), is the second visceral branch of abdominal aorta (Aorta abdominalis) (Damian, 2007). Studies on the cranial mesenteric artery have been performed in dog (Schmidt and Schoenau, 2007), capuchin monkey (Andrade et al. ,2015), buffalo frog (Koichiro et al., 2001), nutria (Culau et al., 2008), porcupine (Atalar and Ylmaz, 2005), raccoon (Lima et al., 2010), opossum (Pinto 
e Silva et al., 2008), rabbit (Uddin et al., 2012; Rada, 2014) and guinea pig (Shively and Stump, 1975).

In the studied source-literature, other results of macroscopic aspects of chinchilla's anatomy have been published in terms of digestive system (Stan et al., 2014; Stan, 2013), nervous system (Irimescu et al., 2014) and cardio-vascular system (Martonos et al., 2014; Özdemir et al., 2013; Özdemir et al., 2008; Gielecki et al., 1996).

Others results focus on histological structure of arteries (Martonos et al., 2015) while others the approach the histological structure of major salivary glands (Matosz et al., 2016).

The aim of this study is to highlight the anatomical features of the cranial mesenteric artery in Chinchilla lanigera and comparing our results with data reported in the literature.

\section{MATERIALS AND METHODS}

The biological material was represented by 10 clinically healthy female chinchilla carcasses, slaughtered by the owner for fur production. The studied animals were subjected to a rigorous clinical exam. In this exam the semiological constants (temperature, breathing, pulse) were recorded.

The next stage was the skinning, followed by the opening of the abdominal cavity on linea alba. In abdominal cavity, the abdominal aorta artery was approached near the cranial aperture of the pelvic cavity and catheterised with a 24G branula. Heparinized serum was injected intraluminally (anti clogging role) followed by a $30 \mathrm{ml}$ acrylic/ latex coloring agent intra-arterial injection. Carcass fixation was performed by immersing these in formaldehyde baths for 5 days. After the satisfactory fixation the stratigraphic dissection was performed. The anatomically-observed aspects were recorded and photographed.

\section{RESULTS AND DISCUSSION}

The cranial mesenteric artery (Arteria mezenterica cranialis), in Chinchilla lanigera species, is the second visceral branch which is detached from the ventral part of the abdominal aorta. This is a solitary branch that arises 1 centimeter caudal to the celiac artery (Arteria celiaca) origin, second lumbar level.

Similarly with chinchillas, the cranial mesenteric artery is described as an individualized branch in case of rabbits (Rada, 2014; Uddin, et al.,
2012; Barone, 1996), porcupine (Atalar and Ylmaz, 2005), raccoon ( Lima et al., 2010), opossum (Pinto e Silva et al., 2008) and nutria (Culau et al., 2008).

Unlike chinchilla, in guinea pig (Shively and Stump, 1975) the presence of a common celiaco-mesenteric trunk (from which the two main arteries are detached after a short traject: celiac artery and cranial mesenteric artery) was reported. The presence of this common celiacomesenteric trunk was also described in some cats, sheep and buffalo specimens (Schmidt and Schoenau, 2007).

From its origin, the cranial mesenteric artery is placed between the blades of the large mesentery. In its traject, at studied species, the cranial mesenteric artery (Fig.1) gives off arterial branches for the largest part of the intestinal mass.

The first branch which is detached from cranial mesenteric artery is the caudal pancreaticoduodenal artery (Arteria pancreaticoduodenalis caudalis). Near the origin of this artery, the origin of the jejunal arteries (Arteriae jejunales) are visible. After jejunal arteries are detached, the cranial mesenteric artery follows a ventro-caudal trajectory and then branch out in the dorsal cecal artery (Arteria cecalis dorsalis)- (for the haustrated part of cecum), medial cecal artery (Arteria cecalis media)- (for the tubular part of the cecum) and iliocecal artery (Arteria ileocolica).

For comparative reasons, in rabbit the cranial mesenteric artery gives off: caudal pancreaticoduodenal artery, jejunal arteries, medial colic artery,ileocecocolic artery and ileal artery (Rada, 2014). In case of Myocastor coypus species, the cranial mesenteric artery branches in the caudal pancreatico-duodenal artery, left colic artery and right colic artery, ileocolic artery, jejunal arteries and ileal artery (Goltz et al., 2013). Almost the same situation has been described in pig. Unlike nutria, in pig, the ileal artery is a branch of the ileocolic artery. (Dondelinger et al., 1998).

In chinchillas, the caudal pancreaticoduodenal artery (Fig. 1) is detached from the traject of the cranial mesenteric artery at 0.5 $\mathrm{cm}$ from its origin on the ventral face of the abdominal aorta. From origin, this artery follows an ventro-cranial trajectory, being disposed between the double blades of the mesoduodenum (Mesoduodenum) and tackle the small curve of the duodenum. In its traject, gives off duodenal branches, a caudal branch anastomotic branch 
for the first retrograde jejunal artery and then forms an anastomotic connection with the cranial pancreaticoduodenal artery (branch of hepatic artery in chinchilla species).
The number of jejunal arteries (Fig. 2) is variable, 4-5 branches being identifiable, depending on individ. These detach as distinct branches from the cranial mesenteric artery close

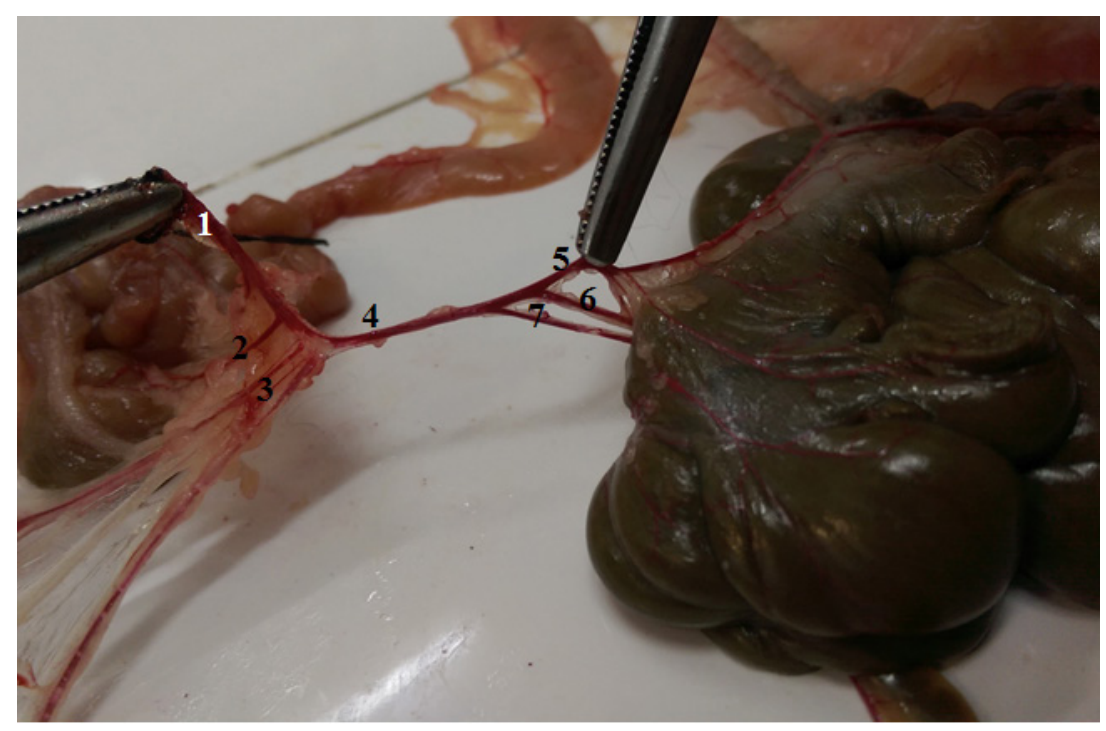

Fig.1. Distribution of the cranial mesenteric artery

1, 4- Cranial mesenteric artery, 2- Caudal pancreaticoduodenal artery,

3- Jejunal arteries, 5- Ileocolic artery, 6- Median cecal artery, 7- Dorsal cecal artery.

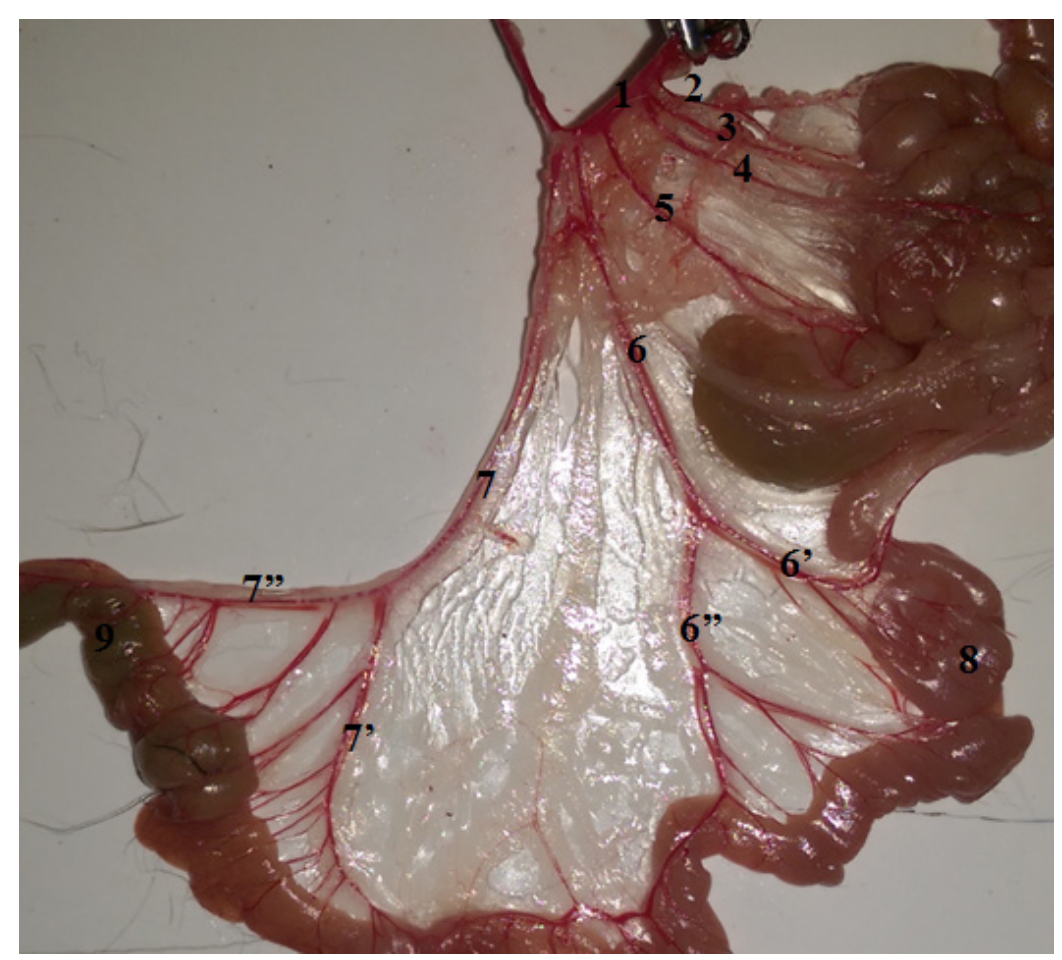

Fig.2. Distribution of jejunal arteries

1-Cranial mesenteric artery, 2-Caudal pancreatico-duodenal artery,

3, 4, 5,6, 7- Jejunal arteries, 6', 7'- Indirect branches, 6", 7'- Direct branches, 8-Jejunum, 9- Ileum. 
to origin of caudal pancreaticoduodenal artery. These branches are disposed between the duble blades of the mesojejunum (Mesojejunum) and head towards the fixed margin of the jejunal mass. Terminally, the jejunal arteries branch out in a direct branch and an indirect/retrograde branch.

The indirect/retrograde branch of the first jejunal artery forms an anastomose with the caudal branch of caudal pancreaticoduodenal artery. The direct branch of last jejunal artery forms an anastomosis with ileonic artery, collateral branch of ileocolic artery.

The number of jejunal arteries varies greatly with the species. In rabbit, the number of jejunal arteries is much higher than in chinchillas where up to 20 branches are reported (Uddin et al., 2012; Mahamed, 2014;). In the Saguinus niger species (Andrade et al., 2015) 14-15 jejunal arteries are mentioned, 6-15 at opossum (Pinto e Silva et al., 2008), 7-14 in nutria (Goltz et al., 2013) and 2025 in pig (Dondelinger et al., 1998). In porcupine (Atalar and Ylmaz, 2005) 10-15 jejunal arteries detached from the level of a jejunal trunk are described. In fox, the literature reports the existence of 3-4 jejunal arteries (Bahgat, 2007).

The dorsal cecal artery (Fig.3) is the first terminal branch of the cranial mesenteric artery, after jejunal arteries detachment. From the origin, this artery follows a ventro-caudal traject, reaching the dorsal surface of cecum. The branches of this artery supply the haustrated part of cecum.

Medial cecal artery (Fig.3) is the second terminal branch of the cranial mesenteric artery and its origin is close of the dorsal cecal artery origin. This artery is responsible for arterial irrigation of tubular part of cecum and the initial portion of the ascending colon.

In contrast to chinchilla, in guinea pig, arterial supply of cecum is provided by an arterial branch detached from the common celiaco-mesenteric trunk (Snipes, 1982).

Ileocolic artery (Fig.3) is the last terminal branch of the cranial mesenteric artery. Its origin is commonly shared with the medial cecal artery.

After a 1,5 cm traject, the ileocolic artery gives off two branches: ileonic artery (Arteria ileonica) and colic artery (Arteria colica).

In porcupine, similar with chinchilla, ileocolic artery is the true continuation of the cranial mesenteric artery (Atalar and Ylmaz, 2005).

In chinchilla the ileocolic artery is disposed between the meso-ileonic blades (Mesoileum) and follows to the small curvature of ileon in antiperistaltic direction. At this level, the ileonic

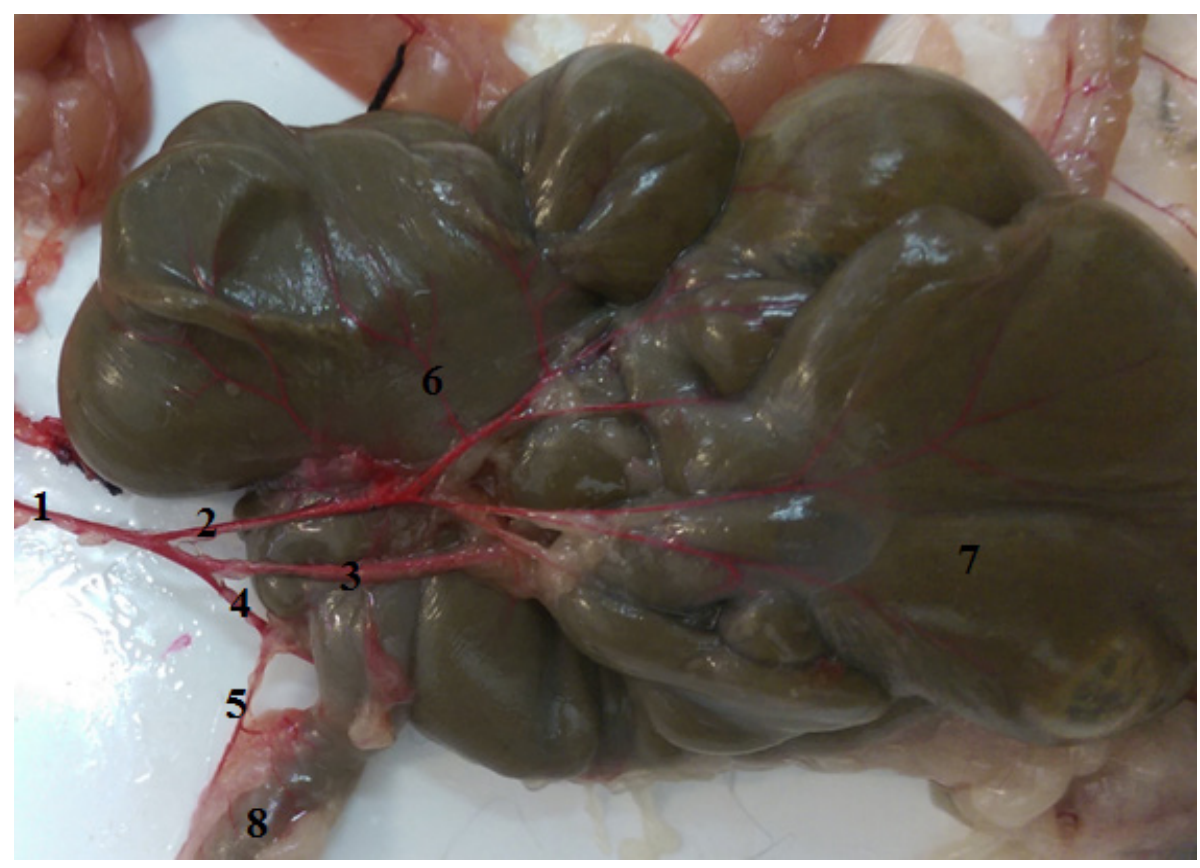

Fig.3. . Terminal branches of the cranial mesenteric artery

1. Cranial mesenteric artery; 2. Dorsal cecal artery; 3. Medial cecal artery;

4. Ileocolic artery; 5. Ileonic artery; 6. Branches for the haustrated cecal part; 7 Cecum; 8. Ileon. 
artery forms an anastomose with the direct arterial branch of last jejunal artery. This gives off perpendicular arterial branches for the fixed margin of the ileum. Unlike chinchilla, in rabbit the ileal artery is a collateral branch of the cranial mesenteric artery and the colic artery is a branch of the ileocecocolic artery (Rada, 2014).

The colic (Fig.4) artery is located between the blades of the cecocolic ligament and it is the true continuation of the ileocolic artery. This ligament connects the ventral part of the cecum with the ascending colon. In its traject, the colic artery gives off arterial branches for the ventral part of the cecum and for the fixed margin of the ascending colon. In the third middle of ascending colon, the colic artery gives off the terminal arteries: cranial colic artery (Arteria colica cranialis) and middle colic artery (Arteria colica media) (Fig.4).
The cranial colic artery supplies the terminal part of the ascending colon while the middle colic artery is responsible for the arterial supply of the transverse colon and most of the descending colon. The middle colic artery forms an anastomosis with right colic artery, an arterial branch of the caudal mesenteric artery (Arteria mesenterica caudalis) in chinchillas.

\section{CONCLUSION}

Our results bring information about the blood supply of intestines in chinchilla, a real help for clinicians and researchers.

In Chinchilla lanigera species, the arterial supply of the most part of the small intestine (except the initial part of duodenum) and most part of the large intestine (except the last part of

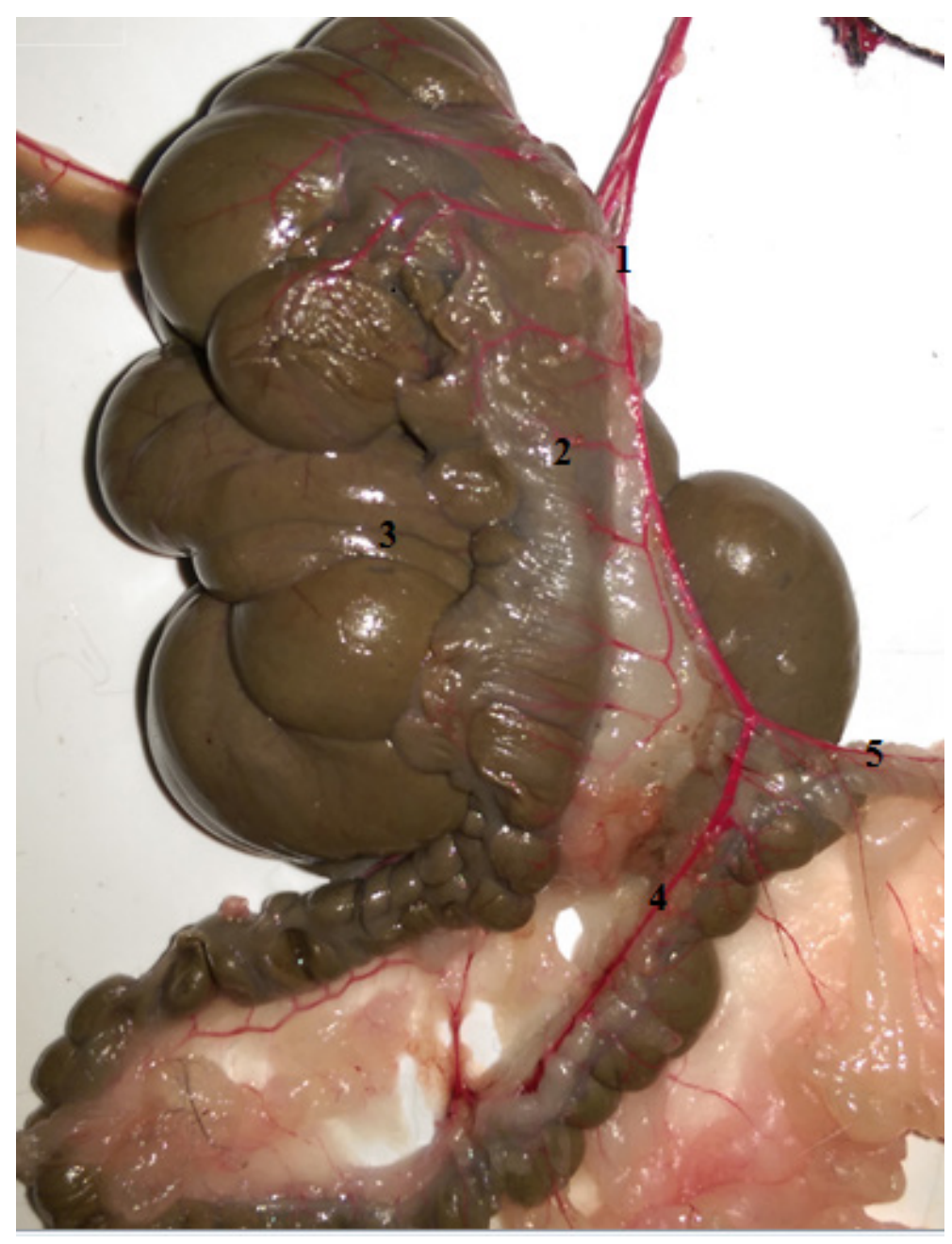

Fig.4. Distribution of colic artery

1- Colic artery, 2- Ascending colon, 3- Cecum, 4- Cranial colic artery, 5-Middle colic artery. 
the descending colon and the rectum) is provided by the cranial mesenteric artery.

The cranial mesenteric artery in the studied species, is the largest visceral branch that arises from the ventral wall of aorta in abdominal cavity.

In chinchilla, the collateral branches of the cranial mesenteric artery are: caudal pancreaticoduodenal artery, jejunal arteries and the terminal branches are: dorsal cecal artery, middle cecal artery and ileo-colic artery.

The jejunal arteries, (4-5 in these species), arise as individual branches on the cranial mesenteric artery's traject. The arterial anastomoses formed by the direct and indirect branches of jejunal arteries, close to the lesser curvature of jejunum forms an true arterial arcade.

\section{REFERENCES}

1. Andrade LC, Branco E, Lima AL (2015). Anatomic study of the collateral branches of the abdominal aorta of primate species Saguinus niger, Anat. Histol. Embryol. 44: 37-42.

2. Atalar O, Ylmaz S (2005).The cranial mezenteric artery in the porcupine (Hystrix cristata), Veterinarski Arhiv. 75(1):75-82.

3. Bahgat $H$ (2007). Some anatomical studies on the mesenteric arteries in the red fox (Vulpes vulpes), $\mathrm{Ph}$. D Thesis. Fac. Med, Benha Univ. Egypt.

4. Barone R (1996). Anatomie comparee des mammiferes domestique; Tome 5, Angiologie Edition Vigot, Paris.

5. Botha M (2009). Influențafactorilor de microclimat asupra perfofmanțelor de reproducție la Chinchilla (Chinchilla Laniger), Teză de doctorat.

6. Bud I, Ștefan R (2006). Animale de blană; Ed. Risoprint, Cluj-Napoca.

7. Bura M, (2003). Chinchilla; Ed. AgroprintTimișoara;

8. Martonos CO, Ruxanda F, Rus V, Miclăuș V, Damian A (2015). Frequency and distribution of muscle cells in some large arteries in chinchilla, Annals of R.S.C.B., Arad, România, doi:10.ANN/RSCB-2015-0008:RSCB.

9. Culau POV, Azambuja RC, Campos R (2008). Ramos colaterais viscerais da artéria aorta abdominal em Myocastor coypus (nutria), Acta Scientiae Veterinariae. 36(3): 241-247.

10. Damian A (2007). AnatomieComparată, Sistemul Cardiovascular, Ed.AcademicPres, Cluj-Napoca.

11. Dondelinger RF., Ghysels MP., Brisbois D, Donkers E, Snaps FR., Saunders J, Deviere J (1998). Relevant radiological anatomy of the pig as a training model in interventional radiology, Eur. Radiol., 8:1254-1273.

12. Gielecki JS, Brudnicki W, Novaki MR, (1996). Digitalimage Analysis of Brain-base Arteries in Chinchilla laniger (Molina), Anat. Histol. Embryol., 25:117-119.

13. Goltz LV, Campos R, Culau POV (2013). Distribuicao das arterias mesentericas cranial e caudal na nutria
(Myocastor coypus), Acta Scientiae Veterinariae, 41: 1146

14. Irimescu I, Chende A, Ghiurco F, Damian A (2014). Anatomical study of the Cerebral Hemispheres in Chinchilla (Chinchilla lanigera). Bulletin of UASVM ClujNapoca,Veterinary Medicine, 71 (1) :130-136.

15. Koichiro I, Kenji K, Hiroyuki K, Takayoshi M, Tatsuo S (2001). A novel branching pattern of the superior mesenteric artery found in the bullfrog (Rana catesbeiana) amphibian, J. Anat., 198: 625-633.

16. Lima VM, Rezende ALS., Ferreira JR, Pereira KF (2010). Distribution of mesenteric cranial artery în the small intestine of Procyon Cancrivorus (Cuvier, 1798) (Mammalia, Procyonidae), Acta Stientinarum. Biological Sciences, Maringa 32(2):175-179.

17. Martonos C, Dezdrobitu C, Rus V, Miclaus V, Irimescu I, Damian A (2014). Distribution of the terminals of the descending abdominal aorta in Chinchillas. Bulletin of UASVM Cluj-Napoca,Veterinary Medicine, 71(1)

18. Martonos C, Dezdrobitu C, Rus V, Miclăuș V, Irimescu I, Damian A (2015). Representation by procentage of the tunicae of the large arteries in Chinchillas. Bulletin of UASVM Cluj-Napoca,Veterinary Medicine, 72(1):185186.

19. Matosz B, Damian A, Rus V, Martonos C, Gal A, Ruxandra F, Miclăuș V (2016). Observations concerning the structure of the major salivary glands in Chinchilla (Chinchilla lanigera). Bulletin of UASVM Cluj-Napoca, Veterinary Medicine, 73(1):111-115.

20. Nomina Anatomica Veterinaria, (2012). Fifth Edition (revised version), Prepared by the International Committee on Veterinary Gross Anatomical Nomenclature (I.C.V.G.A.N.) and authorized by the General Assembly of the World Association of Veterinary Anatomists (W.A.V.A.) Knoxville, TN (U.S.A.) 2003 Published by the Editorial Committee Hannover (Germany), Columbia, MO (U.S.A.), Ghent (Belgium), Sapporo (Japan).

21. Özdemir V, Çevik DA, Akosman MS (2013). Subgross and macroscopic investigation of the coeliac artery in the chinchilla (chinchilla lanigera), Folia Morphol., 18(1):7581.

22. Özdemir V, Çevik DA, Türkmenoğlu I (2008). The right coronary artery is absent in the chinchilla (Chinchilla lanigera). Anatomia Histologia Embryologia, 37:114-117.

23. Pinto e Silva CJR, Martins MRFB, Guazzelli FJ (2008). Study on cranial and caudal mesenteric arteries in opossum (Didelphis albiventris). Int. J. Morphol., 26(3):635-637.

24. Rada AAM (2014). Arterial supply of the intestine of Baladi Rabbit, Inter J Vet Sci, 3(2): 52-60.

25. Schmidt DP, Schoenau LSF ( 2007). Origem das arterias celiaca e mesenterica cranial por tronco comun em cao, Ciencia Rural 37(2): 408-411.

26. Shively MJ, Stump JE (1975). The systemic arterial pattern of the guinea pig: the abdomen, Anat Rec., 182(3):355-66.

27. Snipes RL (1982). Anatomy of the Guinea-pig Cecum, 165:97- 111.

28. Stan F, Damian A, Gudea A, Dezdrobitu C, Delia Bob, Martonos C, Ileana Bochis, Pogana B (2014). Comparative 
anatomical study of the large intestine in rabbit and chinchilla. Bulletin of UASVM Cluj-Napoca,Veterinary Medicine, 71 (1):208-212.

29. Stan F (2013). Comparative Study Of The Stomach Morphology In Rabbit And Chinchilla AgroLife Scientific Journal, 2(2): 73-78.
30. Uddin M, Rahman ML, Alim MA, Ahasan ASML (2012). Anatomical study on origin, cours and distribution of cranial and caudal mesenteric arteries în White New Zealand rabbit (Orycotolagus cuniculus). Internațional Journal of Natural Scinces, 2 (1): 54-59. 